\title{
ORIGINAL (1)
}

\section{パーキンソン病に対する PG-501 の使用経験}

\author{
小坂 健 二*
}

（受付：1971年 7 月 4 日）

\author{
The Beneficial Effect of PG-501 on Parkinsonism \\ Department of Neurology, Faculty of Medicine, Juntendo University \\ Hongo, Bunkyo-ku, Tokyo, Japan \\ Kenji Kosaka
}

\begin{abstract}
We undertooka clinical evaluation of PG-501, 6, 6, 9-trimethyl-9-azabicyclo[3, 3, 1] non-3 $\beta$-yl $\alpha, \alpha$-di (2-thienyl) glycolate hydrochloride, in fourteen patients with Parkinsonism, two with headtremor and one with postural tremor, particularly to observe its effect on tremor.

Improvement in tremor was observed in $78 \%$ of the patients with Parkinsonism and in $100 \%$ of the others. The other symptoms of Parkinsonism, rigidity and akinesia, were improved in 3 of the fourteen patients, but 8 patients experienced improvement in tremor only.

Side effects encountered in certain cases consisted of nausea, anorexia, vertigo and headache, but they disappeared upon discontinuance of administration of PG-501.
\end{abstract}

We conclude that PG-501 is effective in improving tremor caused by Parkinsonism and other diseases.

\section{1. 緒 言}

振戦，筋強剛，無動を主症状とするパーキンソ ン症候群の治療剤としては, 従来ベラドンナアル カロイド，合成中枢性抗コリン剤，また最近注目 されている L-DOPA，アマンタジン等がある。し かし, 従来の抗コリン剂は口渴, 散瞳などのアト ロピン作用が強いことや，長期にわたるとやはり 症状が進行してくるといら難点があることはしば

$*$ 順天堂大学医学部脳神経科
しば経験するところである、今回田辺製薬研究所 にて開発された中枢性抗コリン剂，6，6，9-trimethyl-9-azabicyclo $[3,3,1]$ mon- $3 \beta$-gl a,a-di -thienyl) glycolate hydrochloride 治験略号 PG501 (図 1) は動物実験成績からみて在来の治療剤 に比して振戦に対する拮抗作用が強力であり，散 瞳作用，分泌抑制作用が弱いという結果が得られ た．毒性についてもほとんど認めるべきものがな く，抗パーキンソン剂として臨床的に応用できる ものとして，臨床所見の観察を行つた． 


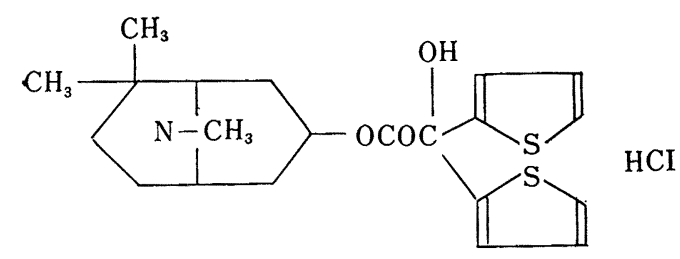

2. 対 象

対象例は特発性パーキンソニスム14例, 頭部振 戦 2 例, 姿勢振戦 1 例の計17例である.

性別は男11例，女 6 例である. 受診時までの罹 患年数はパーキンソニスムの場合は 2 年 1 力月よ り 16 年にわたる. 頭部振戦は 2 年と 4 年, 姿勢振 戦の例は 23 年におよぶ. 受診時年齢は33歳より 66 歳にわたつている.

パーキンソニスム患者は振戦, 筋強剛, 無動の 三主要症状が著明で, 特に静止時振戦が常に認め られるものを対象とした．頭部振戦は頭部, 頸部 に常に振戦が認められるものであるが, 器質性, 心因性いずれのものかは明確に 鑑別できないが従 来の抗パーキンソン剂にて症状が軽減する例であ る. 姿勢振戦 1 例であるがは一定の姿勢を保持す る時に上肢に常に振戦が認められるものを対象と した.

\section{3. 投与方法}

PG-501を 1 日 $6 \mathrm{mg}$ または $15 \mathrm{mg}$ を 1 日 3 回食 後に分服経口投与した. 他の抗パ剂はなる心゙く併 用はさけたが L-DOPA 療法を行なつているもの にはその中止によつて著明な運動障害が 再現され るために離脱できないものがあつた。

\section{4. 評価方法}

パーキンソニスムの 場合は三主要神経症状であ る振戦, 筋強剛, 無動について臨床的に効果を判 定し, その他の精神症状, 自律神経症状, 日常生 活動作についても観察した.

振戦については左右上下肢および軀幹につい て, 筋強剛については左右上下肢について, 無動 については, 歩行, 突進現象, 上肢の回内, 回外
運動, 指打ち試験, 言語障害の程度について効果 を判定し、それらを綜合して無動の効果として一 括して行つた.

$$
\text { パーキンソニスムについてはこの 三主要症状の }
$$

効果判定について一定の基準を設定して効果判定 を行ない，また頭部振戦，姿勢振戦については静 止時の頭部の振戦, 左右上肢を一定の勢姿に保持 した時に出現する振戦について一定の基準を設定 してそれぞれ効果を判定した.

パーキンソニスム, 頭部振戦, 姿勢振戦の振戦 についての基準は,

$$
\begin{aligned}
& \text { 常に認められるもの }-4 \\
& \text { しばしばみられるもの- } 2 \\
& \text { 全くみられないもの }-0
\end{aligned}
$$$$
\text { としそれぞれの中間を } 3.1 \text { とた。 }
$$

筋強剛, 無動む同様に 5 段階にわけ, 筋強剛は 患者の各筋群を被動的に伸展させたときに

$$
\begin{array}{lr}
\text { きわめてつよい筋強剛がある-4 } \\
\text { 明らかに抵抗がある } \\
\text { 全くない }
\end{array}
$$

無動についてはそれぞれの動作について

動作の開始が著しく遅く動作不能—4

動作が明らかに遅い—

全くなし

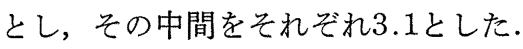

投与前, 後には血液一般検查, 血清 GOT, GPT, アルカリフォスファターゼ，尿所見，心電図，血 液測定を行なつた。表面筋電図検查は全例には施 行していないが効果判定の 補助として使用した.

\section{5. 効 果}

表 1 に17症例を総括してある. パーキンソニス ムについての効果は表 2 にららるように三主要 症状の振戦, 筋強剛, 無動のいずれにも有効であ るのは14例中 3 例であり，振戦のみに有効である 例は14例中 8 例であつた。 したがつて振戦につい ては11例について有効であつた(表 3 ). いずれの 症状も不変であつた例は14例中 3 例であり増悪を 示した例はない. 頭部振戦, 姿勢振戦については いずれも投与によつて改善されている(表 4). 
表 1

\begin{tabular}{|c|c|c|c|c|c|c|c|c|c|c|c|c|c|c|c|}
\hline \multirow{2}{*}{\multicolumn{2}{|c|}{ 氏名 }} & \multirow{2}{*}{$\begin{array}{l}\text { 年 } \\
\text { 齢 }\end{array}$} & \multirow{2}{*}{ 性 } & \multirow{2}{*}{\multicolumn{2}{|c|}{$\begin{array}{l}\text { 罹病 } \\
\text { 期間 }\end{array}$}} & \multirow[b]{2}{*}{ 窎 } & \multirow{2}{*}{$\begin{array}{l}\text { 投 } \\
\text { 量 }\end{array}$} & \multirow{2}{*}{ 投与 } & 振戦 & 筋強剛 & 唖動 & \multirow{2}{*}{$\begin{array}{l}\text { その他 } \\
\text { の㾝状 } \\
\text { の化 }\end{array}$} & \multirow{2}{*}{ 副作用 } & \multirow{2}{*}{ 他剂との併用 } & \multirow{2}{*}{ 効 果 } \\
\hline & & & & & & & & & \begin{tabular}{|l|l} 
前 & 後 \\
\end{tabular} & 前 後 & 爱前 後 & & & & \\
\hline 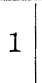 & .Y. & 4 & $\hat{0}$ & $\left|\begin{array}{c}7 \\
10 \text { 力 }\end{array}\right|$ & & 寺 & $6 \mathrm{mg}$ & 7日 & $3 \rightarrow 0$ & $0 \rightarrow 0$ & $0 \rightarrow 2$ & & & & 扎有効 \\
\hline 2 & . I. & 50 & 定 & 16 & & " & $15 \mathrm{mg}$ & 56 日 & $4 \rightarrow 1$ & $3 \rightarrow 2$ & $4 \rightarrow 2$ & \begin{tabular}{|l|} 
仮面榼顔 \\
改善
\end{tabular} & $(-)$ & L-D & 有効 \\
\hline 3 & M. & 66 & 令 & $\begin{array}{l}2 \\
1 \text { 力 }\end{array}$ & & " & $15 \mathrm{mg}$ & 14日 & $3 \rightarrow 1$ & $0 \rightarrow 0$ & $2 \rightarrow 2$ & $\begin{array}{l}\text { 仮面様顔 } \\
\text { 貌改善 }\end{array}$ & $\begin{array}{l}\text { 胃部不快 } \\
\text { 感, 嘔気 }\end{array}$ & & $\begin{array}{l}\text { 振戦に詨 } \\
\text { 有効 }\end{array}$ \\
\hline 4 & K.K. & 56 & 우 & 6 & & "I & $15 \mathrm{mg}$ & 14日 & $2 \rightarrow 2$ & $1 \rightarrow 1$ & $2 \rightarrow 2$ & $(-)$ & 幻視？ & L-DC & 不変 \\
\hline 5 & $\mathrm{~K}$. & 63 & $\hat{0}$ & 7 & & " & $15 \mathrm{mg}$ & 7日 & $4 \rightarrow 1$ & $3 \rightarrow 1$ & $13 \rightarrow 1$ & $(-)$ & $(-)$ & L-DOPA $1.5 \mathrm{~g}$ & 有効 \\
\hline 5 & T. & 48 & $\hat{o}$ & 6 & & "1 & $\mathrm{mg}$ & 日 & $\rightarrow 2$ & $\rightarrow 3$ & $\rightarrow 3$ & $(-)$ & 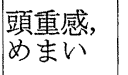 & $(-)$ & $\begin{array}{l}\text { 振戦に対 } \\
\text { L效有 }\end{array}$ \\
\hline 7 & $T$ & 5 & $\hat{o}$ & 3 & & " & $15 \mathrm{mg}$ & 128 & $4 \rightarrow 1$ & $3 \rightarrow 3$ & $33 \rightarrow 3$ & $(-)$ & 幻覚, 幻 & 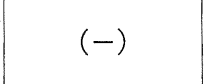 & $\begin{array}{l}\text { 振戦に対 } \\
\text { 乙有効 }\end{array}$ \\
\hline 3 & .H. & 45 & 우 & 3 & & " & $15 \mathrm{mg}$ & 28日 & $3 \rightarrow 1$ & $2 \rightarrow 2$ & $2 \rightarrow 2$ & $(-)$ & $(-)$ & L-DC & $\begin{array}{l}\text { 振戦に対 } \\
\text { 有効 }\end{array}$ \\
\hline 9 & . S. & 5 & 우 & 10 & 年 & " & $15 \mathrm{mg}$ & 14日 & $4 \rightarrow 2$ & $2 \rightarrow 2$ & $2 \quad 2 \rightarrow 2$ & $(-1)$ & $(-)$ & L-L & $\begin{array}{l}\text { 振戦に対 } \\
\text { 效 }\end{array}$ \\
\hline 0 & H.S. & 45 & 7 & 9 今 & & $m$ & $6 \mathrm{mg}$ & 14日 & $2 \rightarrow 2$ & $2 \rightarrow 2$ & $2 \quad 2 \rightarrow 2$ & ( & $(-)$ & L-DOPA $3 \mathrm{~g}$ & 不変 \\
\hline 11 & $\mathrm{~K}$. & 56 & $\hat{0}$ & 5 & & " & $15 \mathrm{mg}$ & 14日 & $3 \rightarrow 2$ & $2 \rightarrow 2$ & $2 \quad 2 \rightarrow 2$ & $(-)$ & $(-)$ & $(-$ & $\begin{array}{l}\text { 振戦に文 } \\
\text { 有效 }\end{array}$ \\
\hline 2 & B.K. & 45 & $\hat{0}$ & 8 & & $\prime \prime$ & $15 \mathrm{mg}$ & 7日 & $4 \rightarrow 0$ & $\rightarrow 2$ & $\rightarrow 3$ & 1 & $(-)$ & $(-)$ & 有効 \\
\hline 3 & H.H. & 52 & 우 & 8 & & "l & $15 \mathrm{mg}$ & 14日 & $3 \rightarrow 2$ & $2 \rightarrow 2$ & $23 \rightarrow 3$ & $(-)$ & $(-)$ & L-DOPA 3g & $\begin{array}{l}\text { 振戦に文 } \\
\text { 有効 }\end{array}$ \\
\hline 1 & . B. & 3 & 今 & 6 & & " & $15 \mathrm{mg}$ & 14日 & $2 \rightarrow 2$ & $2 \rightarrow 2$ & $23 \rightarrow 3$ & $(-)$ & $(-)$ & L-D & 不変 \\
\hline 5 & K.Y. & 45 & 우 & 2 & & 頭部振 & $6 \mathrm{mg}$ & 14日 & $3 \rightarrow 1$ & Y & ノ & $(-)$ & 嘔気 & $(-$ & 有効 \\
\hline 6 & S.M. & 45 & $\hat{\delta}$ & 4 & 年 & $\prime \prime$ & $15 \mathrm{mg}$ & 14日 & $3 \rightarrow 1$ & I & I & $(-$ & $(-)$ & & 有効 \\
\hline 7 & Y.S. & 33 & $\hat{o}$ & 23 & 年 & 姿勢振戦 & $6 \mathrm{mg}$ & 21日 & $4 \rightarrow 1$ & I & I & $(-)$ & $(-)$ & $(-$ & 有効 \\
\hline
\end{tabular}

表 2 ・パーキンソニスム14例に対する

PG-501 の効果

\begin{tabular}{l|c|c|c}
\hline & 有 効 & 不 変 & 増 恶 \\
\hline 振 戦 & $11 / 14$ & $3 / 14$ & $0 / 14$ \\
筋 強 剛 & $3 / 14$ & $3 / 14$ & $0 / 14$ \\
無 動 & $3 / 14$ & $3 / 14$ & $0 / 14$ \\
\hline
\end{tabular}

表 3 14例における振戦のみ有効例と 三主要症状有効例

\begin{tabular}{l|c}
\hline \multicolumn{1}{c|}{ 項 目 } & 例 数 \\
\hline 振戦のみ有効 & $8 / 14$ \\
振戦筋強剛・無動に有効 & $3 / 14$ \\
\hline
\end{tabular}

その他の自律神経症状，精神症状をはつきり出 しているものは少い， 2 例においてパーキンソニ スムに特有である仮面様顔貌が改善され，表情が
表 4 パーキンソニスム以外の PG-501 の効果

\begin{tabular}{c|c|c}
\hline 病 名 & 有 効 & 備 考 \\
\hline 頭部 振 戦 & $2 / 2$ & 振戦以外の症状 \\
姿 勢 振 戦 & $1 / 1$ & はみられない. \\
\hline
\end{tabular}

豊かになつている。

\section{6. 副作 用}

発現した副作用と発現数を表 5 に示す.

表 5 副作用の発現

\begin{tabular}{l|c}
\hline \multicolumn{1}{c|}{ 項 } & 例 数 \\
\hline 胃部不快感, 嘔気 & 2 \\
幻 覚 (?) & 2 \\
めまいと頭重感 & 1 \\
運動減退 & 1 \\
\hline
\end{tabular}


胃部不快感十嘔気, めまい十頭重感はかなり強 く，服薬を中止しなければならない程であつた。 幻覚の症例は，「横にネコが居るような気がする」 という訴えであつたが服薬を中止して消失した。 症例 7 は「夜間泥棒が入つてくるような感じがす る」という訴えでありそのまま投薬をつづけてい るうちに消失した，2例ともに副作用と断定する のには問題があるが後に考察の項でこれについて 述べる。

\section{L-DOPA との併用}

14 例中のパーキンソニスムに掠いてはいずれも L-DOPA を投与しておりいずれも無動，筋強剛 についてはある程度改善されているが振戦がかな りつよい例である. うち10例は L-DOPA の離脱 が不可能であるためにそのまま PG-501を投与し た. 効果については表 6 に示す. 他の抗パ剂は 1 例を除いてすべて中止して行つた。 L-DOPAの 離脱は 4 例にて行つたがいずれも症状の増悪を示 している. その 4 例に対する PG-501投与の効果 は表 7 に示す。

表 6 L-DOPA 療法との併用例 10 例の効果

\begin{tabular}{l|l}
\hline 振戦のみ有効 & $5 / 10$ \\
振戦,筋強剛, 無動に有効 & $2 / 10$ \\
不変 & $3 / 10$ \\
\hline
\end{tabular}

表 7 L-DOPA 離脱後 4 例における効果

\begin{tabular}{l|l}
\hline 振戦のみ有効 & $3 / 4$ \\
三主要症状に有効 & $1 / 4$ \\
\hline
\end{tabular}

\section{8. 臨床検査成績}

血液一般検查, 血清 GOT, GPT, アルカリフ オスファターゼ, 尿検查, 心電図, 血圧についてチ エックを行つたが，特に問題はなかつた（表 8 ).

\section{9. 考察}

パーキンソニスムは振戦, 筋強剛および運動障 害を前景にあらわす無動を三主要神経症状とする 進行性の疾患であり, 脳病理学の上から黒質を中 心とする大脳基底核の変性がみられ, 神経生化学
的検索によつて尾状核，被殼には正常人脳では高 濃度に存在する ${ }^{122) 31}$ ドパミンがパーキンソニスム の患者脳では低下または消失する事実 ${ }^{4)}$ が明かに されてきた。このような事実に基いてパーキンソ ニスムは黒質, 線状体のドパミン代謝障害に本質 的な原因があるのではないかと考えられている。 治療については従来抗コリン剂がある程度症状が 抑えられることが知られており，これまでもこれ ら薬剤使われてきている，乙かし完全にこれらの 症状を抑えることはできず，特に無動については 効果が少ない，そして長期にわたると症状は徐々 に進行していくことが多い，最近になつてドパミ ン代謝障害の想定のもとで L-DOPA 療法が脚光 を浴び実際にかなりの効果をおさめている。しか し L-DOPA 療法も単独で行なうよりは他の薬剤, 例えば抗コリン剤などとの併用で行なつた方がさ らに強力な効果が得られることが経験されてい る.そこで従来の合成中枢性抗コリン剂に比して 強力副作用のよわいものが，以前にも増して求め られてきている.

PG-501 はパーキンソニスムに対して，特に振 戦に対しては明らかに有効である。また，振戦の みを呈する疾患例を選んで投与した結果はやはり 振戦に対して有効であつた。

他の抗パ剂, 例えば Trihexyphenidyl (THP) との比較は二重盲試験などで詳しく検討する必要 があるが，本実験では THP を中止してから PG501を投与し投与中止後再び THP に戻してみる と，振戦については両者にその効果の差はないよ らである。ただし14例中 2 例は PG-501でなけれ ば振戦に対して効果がないために現在まで投与を 続行している. (症例 2 , 症例 7)

筋強剛，無動については全く無効とは言えず表 2 に示すごとく 3 例に有効であり，そのうち表 7 に示すごとく1例は L-DOPA の影響は全くない 場合である.今回は14例中10例は L-DOPA を併 用しているため，また L-DOPA は無動に著効を 示すことで L-DOPA を離脱した対象例をさらに 多く用いれば結果は変つてくるかもしれない. 副作用の幻覚が問題となるが 2 例とも L-DOPA 
表 8 臨床

\begin{tabular}{|c|c|c|c|c|c|c|c|c|c|c|c|c|c|c|c|}
\hline & \multicolumn{2}{|l|}{1} & \multicolumn{2}{|c|}{2} & \multicolumn{2}{|c|}{3} & \multicolumn{2}{|c|}{4} & \multicolumn{2}{|c|}{5} & \multicolumn{2}{|l|}{6} & \multicolumn{2}{|c|}{7} \\
\hline & & \multicolumn{2}{|c|}{ T. Y. } & \multicolumn{2}{|c|}{ O. I. } & \multicolumn{2}{|c|}{ S. M. } & \multicolumn{2}{|c|}{ K. K. } & \multicolumn{2}{|c|}{ E. K. } & \multicolumn{2}{|c|}{ S. T. } & \multicolumn{2}{|c|}{ T. H. } \\
\hline & & 投与前| & 投与中 & 前 & 中 & 前 & 中 & 前 & 中 & 前 & 中 & 前 & 中 & 前 & 中 \\
\hline \multirow{8}{*}{$\begin{array}{l}\text { 血 } \\
\text { 液 }\end{array}$} & |へモグロビン| & 14.0 & 12.1 & 13.0 & 12.8 & 13.0 & 13.0 & 10.3 & 10.4 & 13.0 & 13.0 & 14.1 & 14.0 & 14.5 & 14.0 \\
\hline & 赤血球 & $\begin{array}{r}426 \times \\
16^{4}\end{array}$ & 398 & 450 & 400 & 520 & 420 & 332 & 319 & 390 & 396 & 450 & 448 & 450 & 400 \\
\hline & 白血球 & 7000 & 7000 & 8700 & 7000 & 6500 & 6000 & 3200 & 3400 & 4200 & 7000 & 6000 & 5900 & 6200 & 6000 \\
\hline & 好 中 球 & 68 & 49 & 67 & 60 & 61 & 65 & 78 & 66 & 57 & 35 & 68 & 67 & 58 & 56 \\
\hline & 好 酸 球 & 4 & 4 & 1 & 0 & 1 & 0 & 0 & 0 & 0 & 1 & 1 & 2 & 2 & 4 \\
\hline & 好塩基球 & 0 & 1 & 2 & 0 & 0 & 0 & 0 & 1 & 1 & 0 & 0 & 0 & 0 & 0 \\
\hline & 単 球 & 1 & 0 & 0 & 0 & 1 & 3 & 0 & 5 & 1 & 1 & 1 & 1 & 1 & 1 \\
\hline & リンパ球 & 27 & 43 & 30 & 40 & 37 & 32 & 22 & 28 & 41 & 63 & 30 & 30 & 39 & 39 \\
\hline 生 & ナトリウム & 140 & 138 & 141 & 140 & 135 & 140 & & & 149 & & & & 142 & 140 \\
\hline 化 & カリウム & 3.6 & 3.9 & 3.9 & 3.8 & 3.2 & 3.2 & & & 3.8 & & & & 3.9 & 4.0 \\
\hline 学 & クロール & 129 & 163 & 101 & 103 & 110 & 110 & & & 104 & & & & 105 & 104 \\
\hline \multirow{4}{*}{$\begin{array}{l}\text { 肝 } \\
\text { 機 } \\
\text { 能 }\end{array}$} & SGOT & 18 & 14 & 21 & 18 & 15 & 16 & 17 & 22 & 17 & 15 & 20 & 24 & 0 & 10 \\
\hline & SGPT & 18 & 8 & 12 & 27 & 12 & 10 & 11 & 13 & 17 & 9 & 8 & 11 & 7 & 6 \\
\hline & $\begin{array}{l}\text { アルカリフォ } \\
\text { スフターゼ }\end{array}$ & 6.5 & 7.3 & 7.5 & 6.5 & 6.0 & 7.5 & 7.5 & 7.5 & 6.5 & 5.5 & 6.5 & 7.2 & 8.0 & 7.2 \\
\hline & 黄㾝指数 & 6 & 4 & 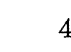 & 5 & 3 & 3 & 3 & 3 & 4 & 5 & 3 & 2 & 1 & 1 \\
\hline \multirow{3}{*}{ 尿 } & 糖 & $(-)$ & $(-)$ & $(-)$ & $(-)$ & $(-)$ & $(-)$ & $(-)$ & $(-)$ & $(-)$ & $(-)$ & $(-)$ & $(-)$ & $(-)$ & $(-)$. \\
\hline & 蛋 白 & $(-)$ & $(-)$ & $(-)$ & $(-)$ & $(-)$ & $(-)$ & $\begin{array}{l}20 \\
\mathrm{mg} / \mathrm{dl}\end{array}$ & 20 & $(-)$ & $(-)$ & $(-)$ & $(-)$ & $(-)$ & $(-)$ \\
\hline & 寉レビリノー & $\mathrm{N}$ & $\mathrm{N}$ & $\mathrm{N}$ & $\mathrm{N}$ & $\mathrm{N}$ & $\mathrm{N}$ & $\mathrm{N}$ & $\mathrm{N}$ & $\mathrm{N}$ & $\mathrm{N}$ & $\mathrm{N}$ & $\mathrm{N}$ & $\mathrm{N}$ & $N$ \\
\hline
\end{tabular}

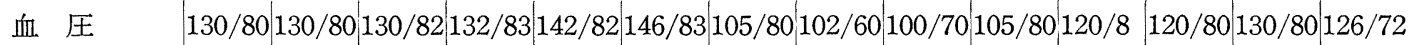

\begin{tabular}{l|l|l|l|l|l|l|l|l|l|l|l|l|l|l} 
心 電図 & $\mathrm{N}$ & $\mathrm{N}$ & $\mathrm{N}$ & $\mathrm{N}$ & $\mathrm{N}$ & $\mathrm{N}$ & $\mathrm{N}$ & $\mathrm{N}$ & $\mathrm{N}$ & $\mathrm{N}$ & $\mathrm{N}$ & $\mathrm{N}$ & $\mathrm{N}$ & $\mathrm{N}$ \\
\hline
\end{tabular}

投与中であり，また L-DOPA は幻覚，幻視を来 すことがまれにある。したがつて PG-501 による ものであるとは断定できない.また,症例 7 の場合 はそのまま服薬続行しているにもかかわらず消失 している点からも副作用か否かはうたがわしい．

頭部振戦はしばしば遭遇する疾患で，原因が器 質性のものか心因性のものであるかの診断が困難 であり治療もなかなかむずかしい，本実験に㧍い て 2 例はこの疾患であるが 2 例ともに有効であつ た。ささらに症例を経験しなければはつきりしない が，有効であるとするならば画期的なことである う.

\section{0. 結語}

パーキンソニスム14例, 頭部振戦 2 例, 姿勢振 戦 1 例計 17 例について PG-501 を投与しその効果 について検討した.

振戦についてはパーキンソニスムにおいては 11 例，他の振戦は 3 例計14例が有効であつた.

パーキンソニスムに㧍ける，筋強剛，無動につ いては 3 例が有効であつた。

副作用では特に重篤なものはみられないが嘔 気，めまいが出現することがある。幻覚が出現す ることがあるが今回は本剤によるものか否かを判 定することはできなかつた。これらは，いずれも 減量, 中止で消失した. 
検 查 成 績

\begin{tabular}{|c|c|c|c|c|c|c|c|c|c|c|c|c|c|c|c|}
\hline \multicolumn{2}{|c|}{8} & \multicolumn{2}{|c|}{9} & \multicolumn{2}{|c|}{10} & \multicolumn{2}{|c|}{11} & \multicolumn{2}{|c|}{13} & \multicolumn{2}{|c|}{15} & \multicolumn{2}{|c|}{16} & \multicolumn{2}{|c|}{17} \\
\hline \multicolumn{2}{|c|}{ K. S. } & \multicolumn{2}{|c|}{ S. A. } & \multicolumn{2}{|c|}{ Y. K. } & \multicolumn{2}{|c|}{ B. K. } & \multicolumn{2}{|c|}{ H. H. } & \multicolumn{2}{|c|}{ K. Y. } & \multicolumn{2}{|c|}{ S. M. } & \multicolumn{2}{|c|}{ Y. S. } \\
\hline 前 & 中 & 前 & 中 & 前 & 中 & 前 & 中 & 前 & 中 & 前 & 中 & 前 & 中 & 前 & 中 \\
\hline 14.2 & 14.0 & 14.4 & 14.0 & 13.0 & 12.8 & 13.0 & 13.8 & 13.2 & 14.0 & 13.8 & 13.4 & 14.0 & 14.0 & 14.2 & 14.6 \\
\hline 420 & 400 & 474 & 424 & 328 & 330 & 440 & 450 & 460 & 400 & 330 & 340 & 440 & 430 & 384 & 400 \\
\hline 4500 & 4200 & $\begin{array}{r}8100 \\
73 \\
1 \\
0 \\
1 \\
25\end{array}$ & $\begin{array}{r}5500 \\
60 \\
1 \\
0 \\
8 \\
34\end{array}$ & 4400 & 4500 & 6000 & 6800 & 7000 & 6000 & 6000 & 6500 & 6800 & 6700 & 5800 & 6000 \\
\hline 138 & 140 & 142 & 143 & 142 & 140 & 142 & 142 & 138 & 135 & 140 & 142 & 138 & 132 & 140 & 142 \\
\hline 3.6 & 3.8 & 4.1 & 4.0 & 3.8 & 3.7 & 3.8 & 3.6 & 3.5 & 3.8 & 4.2 & 4.1 & 3.8 & 4.0 & 4.0 & 3.8 \\
\hline 108 & 106 & 104 & 108 & 102 & $10 \mathrm{~T}$ & 102 & 108 & 102 & 106 & 102 & 101 & 109 & 108 & 100 & 101 \\
\hline 8 & 10 & 17 & 27 & 16 & 17 & 42 & 48 & 18 & 9 & 4 & 6 & 3 & 4 & 3 & 3 \\
\hline 7 & 6 & 10 & 12 & 18 & 6 & 38 & 36 & 6 & 5 & 5 & 4 & 2 & 2 & 2 & 2 \\
\hline 7.5 & 7.5 & 7.5 & 8.0 & 7.0 & 6.0 & 6.0 & 7.0 & 8.0 & 6.8 & 7.0 & 6.9 & 7.8 & 6.8 & 7.0 & 6.8 \\
\hline 1 & 1 & 2 & 6 & 4 & 2 & 2 & 2 & 3 & 2 & 2 & 3 & 4 & 4 & 2 & 2 \\
\hline$(-)$ & $(-)$ & $(-)$ & $(-)$ & $(-)$ & $(-)$ & $(-)$ & $(-)$ & $(-)$ & $(-)$ & $(-)$ & $(-)$ & $(-)$ & $(-)$ & $(-)$ & $(-)$ \\
\hline$(-)$ & $(-)$ & $(-)$ & $(-)$ & $(-)$ & $(-)$ & $(-)$ & $(-)$ & $(-)$ & $(-)$ & $(-)$ & $(-)$ & $(-)$ & $(-)$ & $(-)$ & $(-)$ \\
\hline $\mathrm{N}$ & $\mathrm{N}$ & $\mathrm{N}$ & $\mathrm{N}$ & $\mathrm{N}$ & $\mathrm{N}$ & $\mathrm{N}$ & $\mathrm{N}$ & $\mathrm{N}$ & $\mathrm{N}$ & $\mathrm{N}$ & $\mathrm{N}$ & $\mathrm{N}$ & $\mathrm{N}$ & $\mathrm{N}$ & $\mathrm{N}$ \\
\hline $0 / 80$ & $32 / 84$ & $30 / 80$ & $28 / 38$ & $30 / 80$ & $20 / 60$ & $130 / 80$ & $130 / 80$ & $30 / 80$ & $32 / 12$ & $120 / 60$ & 118.78 & $140 / 92$ & $138 / 82$ & $128 / 80$ & $130 / 62$ \\
\hline $\mathrm{N}$ & $\mathrm{N}$ & $\mathrm{N}$ & $\mathrm{N}$ & $\mathrm{N}$ & $\mathrm{N}$ & $\mathrm{N}$ & $\mathrm{N}$ & $\mathrm{N}$ & $\mathrm{N}$ & $\mathrm{N}$ & $\mathrm{N}$ & $\mathrm{N}$ & $\mathrm{N}$ & z & $\mathrm{N}$ \\
\hline
\end{tabular}

\section{References}

1) Sano, I. et al.: Distribution of catechol compounds in human. Biochem. Biophys. Acta. 32 ; 586-587 (1959).

2) Bernheimer, H. et al.: Herabgesetze Konzentration der Homovanillicsauren in Gehirn von parkinsonkranken Menschen als Ausdruck der Störungs des zentralen Dopaminstoffwechsels. Klin. Wschr., 43 ; 711-715(1965).
3) Bertler, A. : Dopamine in the central nervous system. In biochemical and neurophysiological correlation of centrally acting drugs. ed. by E. Trabucchi. Pergman Press, (1964).

4) Oxford, Bernheimer, $H$. et al. : Zur Differenzieng des Parkinson-Syndroms: Biochemisch-neurohistologische Verleichsunerschungen. Proc. 8 th Int. Congress of Neurology, Vienna, (1965). Wiener Medizinische Akademie, (1965). 